Kürti, László. "Correction to: Kürti, László. Review Article: "Documenting Immigrants, Boarding Houses and Ethnographers. Burdosház Amerikából - Balogh Balázs néprajzkutató nyomában ('A Boarding House from America - in the Footsteps of Ethnographer Balázs Balogh'). Directed by Dezső Zsigmond, produced by Dunatáj Alapítvány, Camera: Arthur Bálint, 2015, 50:39 minutes." Hungarian Cultural Studies. e-Journal of the American Hungarian Educators Association, Volume 10 (2017) DOI:10.5195/ahea.2017.270

\title{
Correction to: Kürti, László. Review Article: "Documenting Immigrants, Boarding Houses and Ethnographers. Burdosház Amerikából - Balogh Balázs néprajzkutató nyomában ('A Boarding House from America - in the Footsteps of Ethnographer Balázs Balogh'). Directed by Dezső Zsigmond, produced by Dunatáj Alapítvány, Camera: Arthur Bálint, 2015, 50:39 minutes." Hungarian Cultural Studies. e-Journal of the American Hungarian Educators Association, Volume 9 (2016) DOI: 10.5195/ahea.2016.237
}

László Kürti, University of Miskolc kurti1953@gmail.com

Abstract: Changing the incorrect word "script" to "scrip". The word "scrip" refers to the method of payment used in companies instead of legal tender. The original article can be found via the DOI: http://dx.doi.org/10.5195/ahea.2016.237

Erratum

Page 234, line 13: 'script' was changed to 'scrip' in the original article.

The sentence should read: "The film then shows bills and purchase books kept in the store but Balogh does not mention that the miners themselves were paid mostly by scrip, a salary system that greatly contributed to their financial exploitation by unscrupulous employers (Bartoletti, 1996, 74-75; Caudill, 1963, 190)."

Full Text Original Article

http://dx.doi.org/10.5195/ahea.2016.237 